steepening of the latitudinal temperature gradient which ultimately brought into existence separate Boreal and Tethyan ammonite realms.

\title{
References
}

Arkell, W. J., 1956. Jurassic Geology of the World. Oliver \& Boyd Ltd., Edinburgh \& London.

Arkell, W. J., Kummel, B. \& Wright, C. W., 1957. Mesozoic Ammonoidea. In: Moore, R. C. (Ed.): Treatise on Invertebrate Paleontology, part L (Mollusca 4), p. L80-L437. Geol. Soc. Amer. and Univ. Kansas Press.

Casey, R. \& Rawson, P. F. 1973. The Boreal Lower Cretaceous. Geological Journal Special Issue 5. Seel House Press, Liverpool.

Gordon, W. A, 1973. Changing geography of Triassic life. Geol. Soc. Amer. Abstracts with Programs, 5, 642.

Hallam, A. 1973. Origin of the Mesozoic 'Boreal' realm. Geol. Mag. 110, 69-70.

Reid, R. E. H. 1973. Origin of the Mesozoic 'Boreal' realm. Geol. Mag. 110, 67-9.

Scheibnerová. V. 1971. Foraminifera and their Mesozoic biogeoprovinces. Records Geol. Survey New South Wales 13 (part 3), 135-74.

Department of Geological Sciences

W. ANTHONY GORDON

University of Regina

Regina, Saskatchewan

Canada, S4S OA2

13th September, 1974.

\section{Classification of the Mediterranean Quaternary}

SIR - I would like to draw attention to some problems of stratigraphical classification presented by the marine Quaternary deposits of the Mediterranean.

They are now commonly divided into six Stages, named, from oldest to youngest, Calabrian, Emilian, Sicilian, Milazzian, Tyrrhenian, Versilian. The first to be defined were the Sicilian (1872), Calabrian (1910) and Tyrrhenian (1914), the definition of each being based on the presence of various molluscan species which had immigrated from the Atlantic. Subsequently the Milazzian (1918), Versilian (1942) and Emilian (1949) Stages were proposed to accommodate deposits laid down during intervals when immigrant faunas were, or were thought to be, altogether absent.

Of the immigrant faunas themselves, none is ubiquitous throughout the Mediterranean region. In recognition of this, Gignoux (1913) concluded that classification must be based not only upon faunas but also upon sea-levels and 'sedimentary cycles'. Such criteria were accordingly included in the original definitions of the Milazzian and Versilian Stages, and have also been included in new definitions proposed from time to time for the other four (Hey, in press). This has led to serious ambiguity, for the relationship between faunal and eustatic changes in the Quaternary Mediterranean is a matter on which there has been much speculation but, as yet, little agreement.

Any further discussion of the classification of these deposits should, of course, take place within the context of the recommendations recently issued by the International Subcommission on Stratigraphic Classification. For the definition of chronostratigraphic units, these require the designation of boundary-stratotypes 'chosen in sequences of essentially continuous deposition at or near markers which are as favorable as possible for long-distance chronocorrelation' (ISSC, 1972, 312). For the base of the Calabrian Stage a boundary-stratotype at Le Castella, Calabria, was proposed in 1965 at the Seventh INQUA Congress, the boundary itself to be defined, as in the original definition of Gignoux (1910), by the arrival of the first cool-temperate Atlantic immigrants. No stratotype, however, has yet been designated for any boundary within the Quaternary.

Geol. Mag. 112 (2), 1975, pp. 201-202. Printed in Great Britain. 
In view of the ISSC recommendations it would clearly be desirable to define these higher boundaries, also, by reference to faunal changes, such changes being generally more useful for long-distance correlation than any which are purely sedimentological. The arrival of the first immigrant mollusca, indeed, has now been recognized in continuous sequences not only in southern Italy but also in northern Italy and in Greece. Their departure, however, has never yet been certainly identified in a continuous sequence either in Italy or elsewhere, and the same must be said of all succeeding arrivals and departures of immigrants, except for one secondary influx in the Calabrian itself. This reflects the fact that, of all the numerous marine Quaternary sequences so far recorded from land-areas in and around the Mediterranean, the majority are both short and discontinuous and none is complete. At one time, indeed, the arrivals and departures not only of the first immigrant fauna but of its successor were thought to be recognizable in the exceptionally long sequences of parts of northern Italy (Ruggieri \& Selli, 1949), but this is now disputed (Ruggieri, 1965).

It is in fact doubtful whether any land-based sequence yet described carries any 'markers' whatever which could be used, in the absence of radiometric or palaeomagnetic dates, for correlation throughout the region. It would therefore appear that the landbased deposits, as known at present, cannot be divided into Stages in accordance with the ISSC recommendations, and that the beds which contain the immigrant faunas must provisionally be regarded as nothing more than assemblage-zones or cenozones (ISSC, 1972, 307).

Conceivably, a complete sequence may yet be revealed by boreholes in some land-area which has undergone continuous subsidence, and this might permit the establishment of a scheme of classification to which the 'traditional' nomenclature could still be applied. Meanwhile, the most nearly complete sequences known are those recently revealed by deep-sea cores, and they, moreover, can be related to the palaeomagnetic time-scale (Cita et al. 1973). If any scheme of chronostratigraphic classification is to be set up in the foreseeable future it may well be necessary, despite the obvious disadvantages, to designate boundary-stratotypes within one or more of these cores.

I thank Mr. N. F. Hughes for helpful comments on a draft of this letter.

\section{References}

Cita, M. B., Chierici, M. A. et al. 1973. The Quaternary record in the Tyrrhenian and Ionian basins of the Mediterranean Sea. In Ryan, W. B. F. et al. 1973. Initial Reports of the Deep Sea Drilling Project, v. 13, 1263-98, Washington D. C.

Gignoux, M. 1910. Sur la classification du Pliocène et du Quaternaire dans l'Italie du sud. C. r. Acad. Sci. Paris, 150, 841-4.

Gignoux, M. 1913. Les formations pliocènes et quaternaires de l'Italie du sud et de la Sicile. Ann. Univ. Lyon, n.s., fasc. 36.

Hey, R. W. (in press). Classificazione del Quaternario marino del Mediterraneo. Riv. Min. Sicil. 145-7.

International Subcommision on Stratigraphic Classification. 1972. Summary of an international guide to stratigraphic classification, terminology and usage. Lethaia 5, 297-323.

Ruggieri, G. 1965. A contribution to the stratigraphy of the marine Lower Quaternary sequence in Italy. Spec. Papers geol. Soc. Am. 84, 141-52

Ruggieri, G. \& Selli, R. 1949. Il Pliocene ed il Postpliocene dell'Emilia. Giorn. Geol. 20, $1-14$.

Sedgwick Museum

R. W. HEY

Cambridge

U.K.

17th September 1974 